\title{
Move Over Managed Care - Health Savings ACCounts, SMALl Businesses, and Low Wage EARNERS: COST, QUALITY, AND ACCESS
}

\author{
Russell B. Cate*
}

TABLE OF CONTENTS

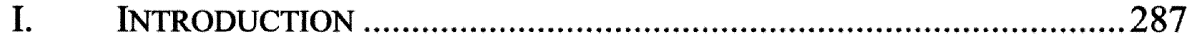

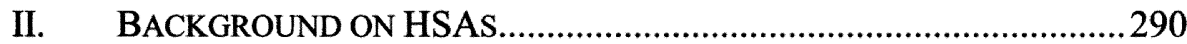

A. The Departure From Managed Care ........................................290

B. Health Savings Accounts .........................................................294

III. CAN HSAS SUCCESSFULLY ACHIEVE COST REDUCTION

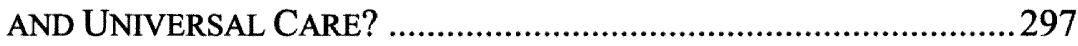

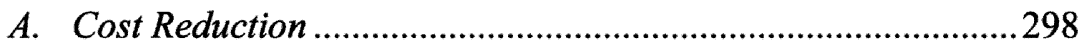

B. Access to Health Care Goods and Services................................303

IV. SMALl BUSINESSES AND THE UNINSURED: STRUGGLES WITH

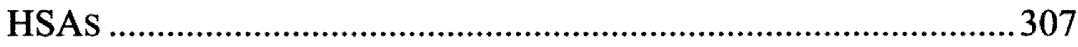

V. PROMISING Alternative SOlUtions to THE High COSTS OF

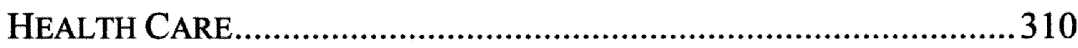

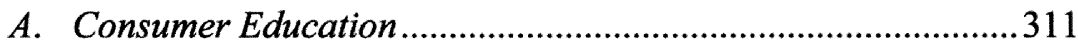

B. Organized Consumer Bargaining Factions ..............................312

C. Health Security for All Americans Act ........................................313

D. Association Health Plans (Small Business Health Plans) ..........315

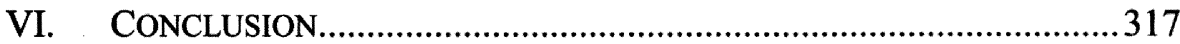

\section{INTRODUCTION}

The high cost of health care in the world's most prosperous nation is becoming an increasingly pervasive problem. Rather than making cost containment and access a function of the government, Congress continues to search for solutions with a capitalistic approach. In other words, Congress continues to leave the task of decreasing health care costs to the marketplace. ${ }^{1}$

* J.D., 2007, Indiana University School of Law, Indianapolis, Indiana; B.A., 2000, Purdue University, West Lafayette, Indiana. I sincerely wish to thank Professor Andre Hampton of the School of Law at St. Mary's University, San Antonio, Texas, whose comments and suggestions provided guidance and encouragement for the completion of this Note. I would also like to thank my wife, Jennifer, and my parents for their love, support, and encouragement.

${ }^{1}$ Andre Hampton, Markets, Myths, and a Man on the Moon: Aiding and Abetting America's Flight from Health Insurance, 52 RUTGERS L. REV. 987, 988 (2000) [hereinafter Hapton, America's Flight from Health Insurance] ("The presumption that the government is wasteful and inefficient is central to the American credo. Adherence to this belief yields a distinctly American mythology. . . [that] [w]e cannot trust the government with too much power to allo- 
As some critics have suggested, however, the health care market differs markedly from other market forums, and thus the same principles that proved successful in the marketplace cannot be successfully applied in the health care context. ${ }^{2}$ On the other hand, advocates of the market solution have hailed the Medicare Prescription Drug, Improvement, and Modernization Act of $2003^{3}$ ("MMA"), which created health savings accounts ("HSAs"), as a potential resolution to the cost containment problems facing the health care industry.

Because they are still in their infancy, little has been written about the effect HSAs have had on the current health care crisis facing America. A basic review of the goals and functions behind HSAs may help to conceptualize how HSAs are impacting the cost, quality, and access problems commonly associated with the health care industry. Generally, "[HSAs] are a new way [to] pay for medical expenses not covered by insurance or other reimbursements."4 HSAs were created to achieve three primary goals: 1) to promote savings for health related expenses, 2 ) to encourage prudent health care spending by providing incentives to consumers, and 3 ) to provide consumers with the ability to select and fund their own health care services. ${ }^{5}$ When put into practice, however, HSAs may be less effective for certain economic brackets of society, such as small business owners and their employees who often may find themselves lower on the socio-economic ladder.

The inclusion of HSAs in the MMA is another piecemeal attempt by Congress to resolve cost containment and access issues without implementing wholesale government intervention to help America finance health care. HSAs are being utilized to avoid the problems associated with managed care that led the market to leave the managed care model and gravitate toward the consumer driven model. The problems with managed care include the following: the inability to control costs, ${ }^{6}$ the amount of responsibility borne by the consumer, ${ }^{7}$ financial risk sharing, ${ }^{8}$ and market failure within the health care industry. ${ }^{9}$ HSAs were designed to alleviate these problems by placing the consumer in control of his/her own finances, thus, ideally forcing him/her to become more

cate resources because the government . . . will squander [them].").

2 Id. at $994-95$.

3 Medicare Prescription Drug, Improvement, and Modernization Act of 2003, Pub. L. No. 108-173, 117 Stat. 2066 (codified as amended in scattered sections of 42 U.S.C. and 26 U.S.C.).

4 Bob Lyke, Chris Peterson \& Neela Ranade, Cong. Research Serv., Health SAVINGS ACCOUNTS 2 (2005), available at http:/www.law.umaryland.edu/marshall/ crsreports/crsdocuments/RL3246701212005.pdf.

5 Id.

6 Andre Hampton, The Princess and The Pea: The Assurance of Voluntary Compliance Between The Texas Attorney General and Aetna's Texas HMOs and Its Impact on Financial Risk Shifting by Managed Care, 83 B.U. L. REV. 553, 588 (2003).

7 Id.

8 Andre Hampton, Resurrection Of The Prohibition On The Corporate Practice Of Medicine: Teaching Old Dogma New Tricks, 66 U. CIN. L. REV. 489, 505-06 (1998).

9 Hampton, America's Flight from Health Insurance, supra note 1, at 996. 
prudent consumers of health care services. ${ }^{10}$ Inherent in the success of HSAs, however, is the assumption that consumers will have available to them the information necessary to make educated decisions about their health care expenditures. ${ }^{11}$

On the contrary, health care consumers generally do not have the information they need to negotiate adequately with potential providers for the most cost efficient service. "Bargaining power disparities are a real phenomenon that can affect the ability of the 'weak' party to obtain its preferred terms in a contractual interaction with a "strong' party." 12 This "phenomenon" has implications in the health care realm because there, consumers and small business employees are the "weak" parties as they do not have access to the necessary information needed to negotiate with the "stronger" health care and service providers demanding payment. The resulting contractual terms tend to favor the health care providers and leave consumers bearing the brunt of health care costs when the federal government is in the best position to assist consumers with excessive health care related expenditures. ${ }^{13}$ This may be especially true for small business owners who may want to offer health plans for their employees but wish to avoid the high costs associated with offering these plans. HSAs provide an alternative to expensive and burdensome health plans, but unfortunately, HSA implementation in the small business context is not likely to succeed because small business employees will not be able to finance the high deductibles associated with HSAs. ${ }^{14}$

Another problem, which often is overlooked, centers on the difficulty low income individuals face when in need of medical care. This segment often consists of small business employees who make too little to afford out of pocket expenses yet generate enough income that disqualifies them from Medicare.

10 John V. Jacobi, Government Reinsurance Programs and Consumer-Driven Care, 53 BUFF. L. REV. 537, 558 (2005) [hereinafter Jacobi, Government Reinsurance] (proposing the government implement a broad reinsurance program to bear most of private coverage's catastrophic costs).

11 John V. Jacobi, Consumer Directed Health Care and the Chronically Ill, 38 U. MrCH. J.L. REFORM 531, 556-57 (2005) [hereinafter Jacobi, Consumer Directed Health Care] (describing the recent development in consumer-controlled spending accounts and suggesting regulatory changes that places catastrophic and chronic health care costs on the government).

12 Daniel D. Barnhizer, Inequality of Bargaining Power, 76 U. CoLo. L. Rev. 139, 150 (2005). Professor Barnhizer distinguishes the legal concept of unequal bargaining power from the practical concept of bargaining power. For purposes of this Note, only the practical concept of bargaining power will be considered.

13 Jacobi, Government Reinsurance, supra note 10. See also Jacobi, Consumer Directed Health Care, supra note 11; Hampton, America's Flight from Health Insurance, supra note 1, at 996 (suggesting that the health care market is an inefficient market unable to allocate appropriately and that government intervention is necessary to remedy the inefficiency).

14 Brian Headd, The Characteristics of Small Business Employees, MONTHLY LAB. REV., Apr. 2000, at 13, 15-16, available at http://stats.bls.gov/opub/mlr/2000/04/art3full.pdf. The article stated that fifty-two and two tenths percent of small firm employees had less than a high school diploma, and in 1998 small firms were responsible for employing more employees requiring government financial assistance than large firms did. Id. 
Ironically, the high cost of goods and services necessary to facilitate quality health care are the same goods and services that are unaffordable for Americans lacking coverage. The United States Census Bureau reports that in 2004, roughly 45.8 million, or fifteen percent, of Americans lacked health insurance coverage. $^{15}$ Small business employees without health coverage can quickly spend what little financial resources they have on necessary medical expenses. The Committee on Education and Labor estimates that sixty percent of workers who are uninsured work for a small firm. ${ }^{16}$ Thus, the lack of available health coverage forcibly drives the low income small business employee farther and farther into debt and poverty. This reality helps to bolster the argument against HSAs because any market based solution to health care cost and access problems will inevitably leave many without coverage. ${ }^{17}$ Supply and demand of market forces should not be allowed to deprive consumers of quality health services.

This Note will briefly discuss the market trend heading toward consumer driven health care and away from managed care. In particular, this Note will review how HSAs can resolve problems of available health insurance to small business employees. Next, this Note will consider the importance of maintaining the dualistic function of HSAs in light of the unequal bargaining power present among small businesses and their employees when compared to the rest of the health care insurance market. This Note will also discuss the difficulties HSAs present for these segments of the population. Finally, this Note will consider several proposed solutions to the problems created by the implementation of HSAs.

\section{BACKGROUND ON HSAS}

\section{A. The Departure From Managed Care}

To better conceptualize this recent shift toward consumer driven health care ("CDHC") it is necessary to gain a basic understanding of its roots. CDHC was essentially an outgrowth of managed care. ${ }^{18}$ "“[M]anaged care,' [is] a variety of organizational arrangements for providing and financing medical care in which the financing entity plays an active role in monitoring and

15 U.S. Census Bureau, Health Insurance Coverage 2004 (2005), available at http://www.census.gov/hhes/www/hlthins/hlthin04/hlth04asc.html. These numbers reflect an increase of 800,000 United States citizens since 2003.

16 Press Release, U.S. House of Rep., Comm. on Edu. \& Labor, Small Business Health Plans: Providing Affordable Health Insurance to Uninsured Working Families, Promoting Small Businesses (Jan. 5, 2007) [hereinafter Small Business Health Plans], available at http://republicans.edlabor.house.gov/PRArticle.aspx?NewsID=9\&IID=13.

17 Hampton, America's Flight from Health Insurance, supra note 1, at 1001.

18 John V. Jacobi, After Managed Care: Gray Boxes, Tiers, and Consumerism, 47 ST. LouIs U. L.J. 397, 404 (2003) (stating that cost, control, and access are problems that were initially remedied by managed care during the mid-late 1990 s, but the problem has returned and new solutions need to be implemented). 
controlling the amount and types of services that physicians provide to patients." In other words, managed care was designed to streamline the insurance and health care functions into one organization. ${ }^{20}$ Prior to managed care, Americans utilized a fee-for-service system that allowed greater flexibility for Americans to choose their health care providers. ${ }^{21}$ The downside was that feefor-service plans required health care related expenses to be paid upfront; reimbursement for these expenses was obtained by submitting receipts to the employer. $^{22}$ This placed an enormous responsibility on patients' shoulders.

The managed care structure began to escalate in popularity during the 1970 s and 1980s. During this period, rapidly increasing health care costs, widespread support for the deregulation of health care, and a strong reliance on market forces helped contribute to managed care's popularity. ${ }^{23}$ Employers who chose to use the managed care model rather than the fee-for-service model began to realize a new method of cost containment. Under the managed care model, health care options were either limited to using either "preferred providers" or enrollment in a health maintenance organization ("HMO") which required them to utilize any physician employed by the HMO ${ }^{24}$ Although the scope of care was limited to providers selected by the employer or HMO, employees under the managed care model benefited from lower insurance premiums and nominal co-payments. ${ }^{25}$

Although fee-for-service programs allowed for a variety of choices in health care providers, these programs did little to control the high cost of health care. Managed care offered a variety of cost containment practices such as "aggressive utilization management ${ }^{26}$ to capitated funding arrangements, limita-

19 Russell Korobkin, The Efficiency of Managed Care "Patient Protection" Laws: Incomplete Contracts, Bounded Rationality, and Market Failure, 85 CORNELL L. REV. 1, 5 (1999).

20 Alice A. Noble \& Troyen A. Brennan, The Stages of Managed Care Regulation: Developing Better Rules, 24 J. HEALTH POL. POL'Y \& L. 1275, 1277 (1999).

21 Ronald Weich, Managed Care and Managed Sentencing - A Tale of Two Systems, 2 FED. SENT'G REP. 139 (1998).

${ }_{22} I d$.

${ }^{23}$ Noble \& Brennan, supra note 20, at 1277.

${ }^{24}$ Weich, supra note 21. See generally Matthew J. Binette, Patients' Bill of Rights: Legislative Cure-All or Prescription for Disaster?, 81 N.C. L. REv. 653, 666 (2003)(discussing the increased enrollment of employees in managed care plans following the adoption of the HMO Act and ERISA).

25 Weich, supra note 21.

26 Jeffrey E. Shuren, Legal Accountability for Utilization Review in ERISA Health Plans, 77 N.C. L. REV. 731,740 (1999) (explaining that utilization management is part of the uniqueness behind HMOs and that utilization review is an objective process to determine whether an individual's medical expenses should be covered or not). A large part of criticism surrounding managed care has involved utilization management and the inability to sue an HMO due to ERISA preemption. "ERISA limits available remedies and precludes the award of compensatory and punitive damages." Id. There have been a number of cases decided by the United States Supreme Court that have centered on this debate. E.g. Aetna Health Inc. v. Davila, 542 U.S. 200 (2004) (explaining how plaintiffs brought suit under Texas state law against their respective HMOs for failure to exercise ordinary care in their coverage decisions. The Court held 
tions on choice of providers, limitations on benefits, exclusive contracting arrangements, and other financial incentives such as bonuses and withholds" in order to help reduce the rapidly increasing cost of health care. ${ }^{27}$ The early success of managed care as a cost containment strategy was initially hailed as the solution to maintaining health care costs. As technology in health care began to escalate, however, the costs associated with that care began to rise and noticeable problems with the system began to emerge.

Among the myriad of problems attributed to the failure of managed care, ${ }^{28}$ two in particular should be discussed because they correlate directly with health care cost inflation. First, over time health care consumers had become passive in their consumption of health care goods and services. ${ }^{29}$ In effect, consumers were over-utilizing the health care industry for minor health ailments, such as the common cold or a minor sinus infection, which normally require no medical attention. ${ }^{30}$ As a result, consumers had little concern for the burdens they were placing on the health care providers because these patients "were fully insulated from costs and had no responsibility for managing care."31 In response, managed care providers attempted to reduce costs by limiting treatment to instances that were medically necessary. ${ }^{32}$ One critic argued that this approach conflicted with what he called "judge made insurance," which is a term used to describe the judicial tendency to interpret contracts based upon what a consumer should have reasonably expected rather than interpreting the contract by its plain language or what the consumer actually expected. ${ }^{33}$ In other words, when an indi-

that plaintiff's cause of action was "completely preempted and was removable to federal court."); Pegram v. Herdrich, 530 U.S. 211 (2000) (The Court denied respondent's claim that when petitioners delayed treatment decisions to increase incentives, they breached a fiduciary duty. The Court held that HMO physicians are not fiduciaries of the HMO and thus there is no federal claim arising under ERISA).

${ }^{27}$ Peter D. Jacobson, Who Killed Managed Care? A Policy Whodunit, 47 ST. Lous U. L.J. 365, 368 (2003). See also Amy L. Cralam, The Serpent in the Garden of Eden: A Look at the Impact of Physician Financial Incentive Programs and a Reconsideration of Herdrich $v$. Pegram, 16 J.L. \& HEALTH 289, 308-18 (2002) (discussing various types of cost containment practices used by managed care organizations).

28 Jacobson, supra note 27, at 390-92 (suggesting the managed care industry may be responsible for its own undoing). Additional factors contributing to the decline of managed care include: poor implementation of the managed care concept, the propensity of the industry to avoid responsibility for its part in clinical decisions, a severe lack of information made available to the public, and the industry's concentration on public relations and failure to devote resources to advancing the quality of health care. $I d$.

29 Brian J. Marcotte, How Employers Can Make Consumer-Driven Health Care a Reality? in Consumer-Driven HEAlTh CARE: IMPLICATIONS For PROVIDERS, PAYERS, AND POLICYMAKERS 213-23 (Jossey-Bass 2004).

${ }^{30}$ See Wendy K. Mariner, Can Consumer - Choice Plans Satisfy Patients?, 69 BroOK. L. Rev. 485, 496 (2004) (discussing how consumer driven health plans help remedy this problem by placing the responsibility for medical treatment decision making directly on the consumer).

31 Marcotte, supra note 29, at 213-23.

32 Jacobson, supra note 27.

33 E. HaAvi Morreim, Holding Health Care Accountable: law and the New MEdical MARKETPLACE 45 (Oxford Univ. Press 2001). 
vidual signs a contract for insurance coverage it is likely that they will not consider all the implications of the terms contained in a particular agreement. As a result, they may be signing a document that provides for less coverage than expected. $^{34}$ Thus, this judge made insurance is most noticeable in judicial opinions involving payment and coverage that were favorable to patients seeking care that was not actually covered by their insurance contracts. Unfortunately, the managed care industry was viewed as effectively discouraging patients from utilizing health care services for minor ailments that had the potential of developing into more severe conditions. Limitations on access to medical treatment lay the foundation for the second problem associated with managed care.

The second set of problems associated with managed care involves the difficulty in establishing a provider's liability for negligence, fraud, substandard care, or denial of benefits. This is an area where, beginning in the early $1990 \mathrm{~s}$, the federal government began to take a more active role in managed care regulation. ${ }^{35}$ For example, the United States Supreme Court has ruled in several cases that a state cause of action against a managed care provider was preempted by the Employee Retirement Income Security Act of $1974 .^{36}$ Patients injured by a managed care provider's decision to deny benefits are only able to recover actual losses. ${ }^{37}$ Therefore, patients whose medical expenses are covered

34 Id. As Dr. Morreim pointed out, judges have a tendency to interpret contracts consistent with the expectation of the consumer rather than interpreting the contract consistent with the terms of the agreement. In effect, the judicial system has assumed the responsibility of dictating the terms of some insurance contracts. This may be attributed to a judge's propensity to interpret contracts consistent with the canon of construction that suggests contracts should be universally interpreted against the drafter, or it may be as simple as a particular judge's dislike of large insurance companies. Either way, limiting treatment to what the insurance company deems is medically necessary may become impossible with practices such as "judge made insurance."

35 See Brian Biles \& David Sandman, Ensuring Equal Access to Care, in REGULATING MANAGEd CARE TheORY, Practice, AND Future OPTIONS 135, 139 (Stuart H. Altman, Uwe E. Reinhardt, David Shactman eds., 1999) (discussing policymakers' attempts to respond to consumer concerns about access to health care in the managed care industry). See also Binette, supra note 24 (analyzing the legislative steps some states have taken to promote patients' rights).

36 See, e.g., Aetna Health Inc. v. Davila, 542 U.S. 200 (2004); Pegram v. Herdrich, 530 U.S. 211 (2000). See also Aaron S. Kesselheim \& Troyen A. Brennan, The Swinging Pendulum: The Supreme Court Reverses Course on ERISA and Managed Care, 5 YALE J. HEALTH POL'y L. \& ETHICS 451 (2005); Noble \& Brennan, supra note 20. But see Larry J. Pittman, $A$ Plain Meaning Interpretation of ERISA's Preemption and Savings Clauses: In Support of a State Law Preemption of Section 1132(A) of ERISA's Civil Enforcement Provisions, 41 SAN DIEGo L. REV. 593 (2004) (suggesting that ERISA's savings clause promotes federalism by design).

37 Eric M. Eusanio, Control, Quality, and Cost: The Need for Federal Legislation Amending ERISA's Failure to Protect Consumers From Liability-Free MCOs, 7 J.L. \& PoL'Y $627,646-47$ (1999) (“Although ERISA's enforcement provisions provide judicial remedies to seek relief for breaches of contractual or fiduciary obligations, the statute has been interpreted as failing to provide a mechanism by which employee-consumers can seek redress for injuries caused by the direct negligence of their MCOs."). 
by managed care providers have no adequate redress for errant treatment decisions. ${ }^{38}$ This problem is compounded by the lack of information available to consumers necessary for them to make prudent decisions regarding their health care. $^{39}$

Managed care in its current form will not soon be entirely replaced by another form of health care regulation. This does not, however, negate the need for an alternative means to regulate problems within the health care market. " $[\mathrm{R}]$ ecent history has demonstrated [...] managed care plans, even as modified in reaction to backlash, are not well suited to serve the goals of increasing access, containing cost and assuring quality, absent a non-market public policy intervention." ${ }^{, 40}$ Thus, the final solution to cost and access problems does not end with the failure of managed care. Rather, other health care financing alternatives seem to be rapidly gaining in popularity as a result of legislative and executive initiatives to alter the face of health care access.

\section{B. Health Savings Accounts}

The movement away from managed care has been spearheaded by a movement toward consumer driven health plans ("CDHPs"). ${ }^{41}$ A relatively new concept, the premise for these CDHPs was stated by one proponent as being "fundamentally about empowering health care consumers - all of us - with control, choice, and information." 42 Furthermore, this "[c] onsumer control will reward innovative insurers and providers for creating higher-quality, lower-cost

38 In July of 2005, a jury awarded nine million dollars to Peter John Smelik after he filed suit against Humana Health Plan of Texas, Inc., among others, essentially for mismanaging managed care. As a practical matter, a cause of action for mismanaging managed care presents a new cause of action against HMOs that is not preempted by federal ERISA law. In re Humana Health Plan of Tex., Inc., 2005 Tex. App. LEXIS 5389. See Physicians For A NATIONAL Health Program, JuRy Awards \$7.4 Million IN Wrongful Death Lawsuit Against HUMANA HMO (2005), available at http://www.pnhp.org/news/2005/july/jury_awards_74_mil.php. See also AIS Managed CARE, Health Plan LaWsuit Watch (2005), available $\bar{a}$ http://www.aishealth.com/ManagedCare/HMOLawsuitWatch/Smelik_v_Mann.html (explaining that the case was actually settled before trial but Texas law requires jurors to assign blame among defendants).

39 See infra text and notes accompanying Parts III.B, V.A.

40 Jacobi, After Managed Care, supra note 18, at 409. See also Melissa Ganz, Note, The Medicare Prescription Drug, Improvement, \& Modernization Act of 2003: Are We Playing the Lottery With Healthcare Reform?, 2004 DUKE L. \& TECH. REV. 11 (2004) (suggesting that the current status of American health care is insufficient to address the needs of the population); Jacobi, Consumer Directed Health Care, supra note 11, at 541-42 (suggesting that the movement toward CDHPs may likely have been the result of managed care's inability to accurately respond to a consumer market "that valued price, [either] because the structure of third-party health coverage created agency problems, because employees lacked appropriate information or the ability to use it, or because members lacked the ability to choose their plan.").

41 Jacobi, Consumer Directed Health Care, supra note 11, at 536.

42 REgINA E. HERZLINGER, CONSUMER-DRIVEN HEALTH CARE: IMPLICATIONS FOR PROVIDERS, PAYERS, AND POLICYMAKERS xvii (Jossey-Bass 2004). 
services we want and deserve."43 Thus, the success of CDHPs will depend on the consumer's ability to access and apply information obtained through a variety of mediums on the various benefits of each CDHP when one is making health care consumption-related decisions.

The consumer, however, has two essential decisions to consider when evaluating available information. First, consumers must decide how much of their financial resources will be attributed to their respective HSA. More than likely the consumer will make this decision when in good physical and mental health. ${ }^{44}$ As a result of underestimating the likelihood of a future need for medical attention, there may be a tendency to underfund his or her account. Conversely, the second decision may require a consumer to make a purchasing decision as a patient in need of medical attention rather than as a healthy consumer. Thus, the risk of under-funding can occur when consumers make naïve, irrational, or ill informed decisions regarding their HSAs. ${ }^{45}$ The underlying problem is that consumers who are in good health may not rationally consider what type of funding is necessary for adequate future health care. Consequently, when health care becomes necessary, the HSA may be insufficient to cover health care costs.

Generally, a CDHP is a savings plan involving an account where one may deposit funds before taxes are paid and then utilize these funds for medical related expenses, tax free. ${ }^{46}$ Several types of CDHPs exist, such as HSAs, Medical Savings Accounts, Flexible Spending Accounts, and Health Reimbursement Arrangements. ${ }^{47}$ The most significant of these plans was introduced when President George W. Bush signed the Medicare Prescription Drug, Improvement, and Modernization Act of 2003 ("MMA"). ${ }^{48}$ This Act introduced health savings accounts that allow participants to "accumulate funds for health care and other purposes." their own funds to purchase health care goods and services, consequently, forcing consumers to become more informed and prudent about their health care related spending decisions.

HSAs require that the individual seeking to open an account has health in-

43 Id.

44 Jacobi, Consumer Directed Health Care, supra note 11, at 557.

45 Arti K. Rai, Reflective Choice in Health Care: Using Information Technology to Present Allocation Options, 25 AM. J.L. \& MED. 387, 393-94 n.57 (1999) (suggesting that information technology is essential to informing consumers about health care financing options.).

46 Alden J. Bianchi, Options in Consumer-Driven Health Care: HSAs, HRAs, and FSAs, Medicare Reform, Health Savings Accounts and the Future of Consumer Directed Health Care, 64 A.L.I. 1061, 1063 (2005).

47 Marshall B. Kapp, Patient Autonomy in the Age of Consumer-Driven Health Care: Informed Consent and Informed Choice, 2 J. HEALTH \& BIOMED. L. 1, 19-20 n.105, 106 (2006).

48 Medicare Prescription Drug, Improvement, and Modernization Act of 2003, Pub. L. No. 108-173, 117 Stat. 2066 (codified as amended in scattered sections of 42 U.S.C. and 26 U.S.C.).

49 Bianchi, supra note 46. 
surance coverage under a high deductible health plan ("HDHP"). ${ }^{50}$ "An [sic] HDHP is a health insurance plan structured similar to a traditional plan but with markedly higher out-of-pocket deductibles." ${ }^{51}$ Usually, the HDHPs are required to have a one-thousand dollar deductible for individuals and a twothousand dollar deductible for families before an individual's respective HDHP would begin to cover costs. ${ }^{52}$

HSAs also tend to be more flexible for the account holder than other CDHPs. For example, funds deposited into an HSA carry over from year to year with the only stipulation being that the consumer must meet the required deductible at the beginning of each year. ${ }^{53}$ Furthermore, HSA balances may be withdrawn in cash, and they may be funded by "the eligible individual, his or her employer, a relative, or any combination of these sources." ${ }^{\text {,54 }}$ The flexibility offered by HSAs makes it an appealing alternative to large employers who are looking to reduce health related spending. While HSAs may initially be attractive to small employers, the attraction is mostly favorable numbers small employers see on paper. Employees who decide to open an HSA will realize benefits from a different perspective. They will be forced to become prudent consumers of their own health care by researching, processing, and applying information about which health-related goods and services they should allocate their finances towards.

The flexibility of, and tax benefits that flow from, HSAs are purported to be what is likely to push HSAs to the forefront as the predominant form of CDHPs. "Through this mechanism, consumers are encouraged to participate in a genuine market for health care services, making judgments, as with any consumer purchase, as to the utility of spending as opposed to saving 'their' money." ${ }^{, 55}$ As a result, consumers have a more direct stake in their own health care expenditures and will likely exercise greater discretion in selecting which medi-

50 According to the MMA, an HDHP is a plan that has an annual deductible of at least one thousand dollars for self coverage and at least two thousand dollars for family coverage. Additionally, the sum of the annual deductible and annual out of pocket expenses (excluding premiums) does not exceed five thousand dollars for self-only coverage and ten thousand dollars for family coverage. 26 U.S.C.A. $\S 223$ (West Supp. 2007).

${ }_{51}$ J.M. Razor, Health Savings Accounts: Increasing Health Care Access in America?, 17 LOY. CONSUMER L. REV. 419, 422-23 (2005). For a simple discussion of HDHPs and a clear explanation of HSA contribution and distribution, see U.S. TREASURY, ALL ABOUT HSAS (2006), http://www.treas.gov/offices/public-affairs/hsa/pdf/all-about-HSAs_051807.pdf.

52 Michelle Andrews, The Promise and The Pitfalls Of Health Savings Accounts, N.Y. TIMES, Aug. 14, 2005, at $\S 3$; see also Bianchi, supra note 46 (elaborating on the specifics of HDHPs and HSAs).

${ }_{53}$ Charles H. Klippel, The Implications of Tax Rulings on "Savings Accounts," in CONSUMER-Driven Health CARe IMPLiCATIONS FOR PROVIDERS, PAYERS, AND POLICYMAKERS 279, 282 (Jossey-Bass 2004).

${ }^{54}$ Id. See also Richard L. Kaplan, Who's Afraid of Personal Responsibility? Health Savings Accounts and the Future of American Health Care, 36 MCGEORGE L. REV. 535, 549 (2005).

Jacobi, Government Reinsurance, supra note 10, at 557. 
cal goods and services they wish to consume, if they even elect to do so at all. ${ }^{56}$ Consumers also have the choice to inadequately fund their HSAs or to forego medical treatment for certain ailments in order to retain funds. Medical treatment options may then be limited based on the amount of HSA funds available to a respective individual. This line of reasoning may have negative implications because if an employee foregoes treatment due to expense, that same employee risks exacerbating the condition which will, in turn, cost not only the employee, but also the employer, more in future expenses. In other words, if an employee's condition were to deteriorate, new and more expensive treatment may be necessary thus forcing the employee or their employer to help fund costs associated with the necessary treatment. Unfortunately, such a course of action forces one to utilize already scarce, expensive resources driving costs of health care even higher.

With HSAs, a new wave of health care financing has arrived, but it has been slow to gain in popularity. ${ }^{57}$ Nevertheless, it is a generally accepted principle that the current status of American health care is insufficient to address the needs of America's continually growing population. Speaking of the nation's current health care system, one critic of the system suggested that "[w]hile increased expenditures represent a stable economic status and evidence of our nation's ability to pay for life extending health care, it is undeniable that the ... system is insufficient and unsustainable."58 Thus, the move toward CDHC has led to the evolution of a new free market within the health care industry. HSAs will likely succeed in "institutionaliz[ing] the individual account approach to medicine," health care costs.

\section{CAN HSAS SUCCESSFULLY ACHIEVE COST REDUCTION AND UNIVERSAL CARE?}

Managed care immediately addressed the needs of the American population when implemented. Ironically, the same system that was designed to lower the cost of health care actually raised expenditures when Americans began to seek excessive medical care for minor health related issues. As discussed, once managed care realized this, the system put in place a number of cost containment strategies that adversely affected the consumer. Congress intended the

56 Id. at 558.

57 For discussion addressing the potential of HSAs, see Barry Kozak, New Health Savings Accounts Promote Consumer Driven Health care, 18 C.B.A. REC. 58, Apr. 2004; Angel B. McCall, Health Savings Accounts May Reduce Health Insurance Costs, COLORADO LAWYER, 57, Jan. 2005; Scott E. Vincent, IRS Encouraging Use of Health Savings Accounts by Issuing Model Forms, Journal OF THE Missouri BAR, 194, July-August 2004.

58 Ganz, supra note 40, at 1.

59 Edward Zelinsky, The Defined Contribution Paradigm, 114 YALE L.J. 451, 508 (2004). 
Medicare Prescription Drug, Improvement, and Modernization Act of 2003 and its provision creating HSAs to be a resolution for the high costs of health care.

With "[t]he new millennium announc[ing] a new era, the consumer era... .People want to be responsible for their own destiny. . . . They want to buy goods and services they think they need, exercising what is known as purchasing power. ${ }^{\circ 60}$ Generally, consumers prefer to control their own finances and enjoy making informed purchasing decisions. Thus, it is imperative that consumers have the ability to access, analyze, and apply available information ${ }^{61}$ in order for the consumer to make "an informed decision about the type and amount of health care to purchase." ${ }^{\prime 62}$ The problem is ascertaining, even with access to this information, whether the patient has the ability to compare the quality of health care of one provider to the quality of health care available within the rest of the market. ${ }^{63}$ Educating consumers on the type of responsible research that is necessary prior to making purchasing decisions within the health care market is essential because if HSAs are to be successful it will require educating the population on the costs and alternative cheaper methods of health care. Intelligent consumers will theoretically be more prudent consumers, subsequently lowering health care costs. Tied closely with the costs of health care is public access to health care. By lowering costs, access should be increased to those who were previously unable to afford quality health care.

\section{A. Cost Reduction}

The rise in health care costs can be attributed to a number of factors such as patients' inability to pay, poor hospital management, governmental regulations and compliance costs, and expensive advancements in health care technology ${ }^{64}$ The inherent nature of HSAs is to reduce these costs by increasing information technology, such as information available over the internet that is available to the consumer thus empowering them to make more informed purchasing decisions. ${ }^{65}$ The internet is likely the least expensive means of delivering information to large segments of the population. The problem, however, is that even if this information is made available through government supported financing and legislative action aimed at developing minimum technological

${ }^{60}$ Alvaro Salas-Chaves, Consumer-Driven Health Care An International View, in

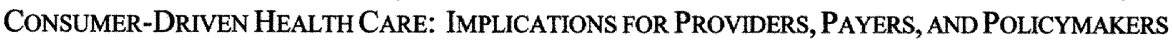
362, 363-64 (Jossey-Bass 2004).

61 See Thomas L. Greaney, How Many Libertarians Does It Take to Fix a Health Care System?, 96 MICH. L. REV. 1825, 1831 (1998) (stating that information in the health care industry is insufficient causing consumers to unnecessarily place greater reliance on provider judgments).

62 Jacobson, supra note 27, at 391.

${ }^{63}$ Id.

${ }^{64}$ Kelsey D. Patterson, Healing Health Care: Fixing a Broken System with Information Technology, 14 KAN. J.L. \& PUB. POL'Y 193, 195-98 (2004).

65 Id. at 203-14. 
standards, the costs associated with, and lengthy processes involved, would do little to address the immediate needs of the marginalized population in America. $^{66}$

HSAs compound these issues because an HSA is distinct from managed care and traditional insurance because they place a higher burden on consumers with respect to their health care consumption decisions. ${ }^{67}$ Health care consumers now, more than ever, must be aware of what goods and services are necessary to purchase, what a fair market price is for those goods and services, and whether less expensive, yet higher quality, alternative care options are available. $^{68}$ The ability to redress these issues ex ante is difficult even with adequate information about the choices of health care providers

Of course, the immediate success of HSAs and CDHPs typically depends on the consumer's ability to select health care wisely. One critic suggests that success depends on two assumptions: first, that the consumer will make the most cost-efficient purchasing decisions, and second, that consumers will not face buyer's remorse about their ex ante decision once they become patients. ${ }^{69}$ Consumers often do not consider the need for future traumatic health care, and "when [a] transplant is needed, the consumer [becomes] a patient and may resist enforcement of any contract that denies coverage." ${ }^{, 70}$ Convincing consumers about the importance of their spending decisions plays an important role in the educational process of implementing HSAs and may help move away from judge-made insurance, which is often the result of a health care consumer's spending decisions.

Consumer education on health care selection may also lower costs by improving consumer bargaining positions. Currently, a dichotomy in bargaining for contractual health care rights exists between consumers purchasing health care in their capacity as consumers versus patients. Disparities in bargaining power can have detrimental effects on the consumer's ability to obtain a favorable contractual provision from a "stronger" health care provider. ${ }^{71}$ Consumers purchasing health care in their capacity as consumers are likely to experience this disparity when they arrive at the proverbial negotiating table because they lack the necessary information needed to place them in a superior bargaining

66 Information is commonly accessed via the internet and is usually too difficult to analyze and interpret to be of any use to the consumer, especially consumers lacking formal education. Louise G. Trubek, Lawyering for a New Democracy: Public Interest Lawyers and New Governance: Advocating for Health Care, 2002 WIS. L. REV. 575, 589 (2002).

67 Jennifer L. Spiegel, Comment, Employee Driven Health Care: Health Savings Accounts, More Harm Than Good, 8 U. PA. J. LAB. \& EMP. L. 219, 223-24 (2005).

68 Id.

69 Mariner, supra note 30, at 514-17 (discussing skepticism that complete information disclosure may still be insufficient to meet consumer needs and promote cost efficient consumption).

70 Id. at 515.

71 Barnhizer, supra note 12. 
position. ${ }^{72}$ The very nature of a consumer acting as a patient places one in an inferior bargaining position because the consumer must obtain medical care in some fashion leaving little room for negotiation. Furthermore, when contracting for health care, consumers, acting in either capacity, encounter arbitration clauses denying them the ability to sue and "strip[ping] them of a valuable right at a time when they might be at their most vulnerable."73 Thus, education would create awareness and increase bargaining power among consumers helping to drive down costs.

HSAs, however, rely on the premise that those utilizing them as a form of health care financing will act as prudent consumers. The problem is that in the health care marketplace, Americans are not acting like consumers because their role is too passive. ${ }^{74}$ When an individual is not held financially responsible for his or her spending and consumption decisions, there is no incentive to curtail spending. The current health care system provides consumers with no restrictions regarding their spending decisions, creating a subjective decision to be made by each consumer as to what goods and services are medically necessary. Ascertaining what each individual consumer will subjectively demand with regard to medically necessary health care services creates arbitrary, and potentially dangerous, outcomes. One individual may believe that an expensive prescription antibiotic is the only way to remedy a common sinus infection, while another individual may choose to wait because they do not want to take time to visit the doctor to obtain a prescription. Nevertheless, in both scenarios neither consumer is considering the financial impact of his or her decision. Each decision is made based upon personal preference rather than sound medical knowledge as to the ramifications of choosing one approach over the other.

Another drawback is that HSAs leave to the consumer the responsibility of considering difficult treatment decisions when the need for such treatment is unforeseeable. ${ }^{75}$ It seems that most Americans do not like to consider such sce-

72 See George W. Bush, President of the United States, The President's Address to the Nation (Jan. 24, 2004), available at http://www.whitehouse.gov/news/releases/2004/01/20040124.html ("We should help more small businesses afford health insurance for their workers by allowing these firms to band together and negotiate for lower insurance rates. These Association Health Plans give small employers the same bargaining power as big companies, making it easier for them to provide employee health coverage.")(statement of President Bush).

${ }_{73}$ Katherine Kuhn Galle, The Appearance of Impropriety: Making Agreements to Arbitrate in Health Care Contracts More Palatable, 30 WM. MITCHELL L. REV. 969, 970 (2004). But see MORREIM, supra note 33.

74 Edward Larson \& Marc Dettman, The Impact of HSAs on Health Care Reform: Preliminary Results After One Year, 40 WAKE FOREST L. REV. 1087, 1107 (2005).

"[O]ne of the big problems we have in health care today is we do not act like consumers. We have third-party payers paying the bills, and so when we go and pay for health care, someone else is paying the bills, so we really do not care how much it costs. That is one of the reasons why the costs of health care are going up through the roof."

Id. (quoting Representative Ryan, 149 Cong. Rec. 6005).

75 See Jacobi, Consumer Directed Health Care, supra note 11, at 556-57. 
narios until they are forced to confront them directly. Consequently, Americans with HSAs may not plan ahead for health coverage that falls under the HSA minimum deductible. HSAs were designed to place the health care expenses that fall under the deductible on the shoulders of the consumer. ${ }^{76}$ This means that the responsibility of providing the first several thousand dollars of coverage is left up to the consumer. If the account is underfunded when coverage is needed, a respective consumer may elect to forego treatment. Thus, the failure to plan ahead on a large population scale may lead to unforeseen problems with HSAs, such as creating an economic class impoverished by excessive medical expenses. $^{77}$

So while HSAs posit to reduce health care costs and subsequently increase the amount of Americans able to afford health coverage, they are subject to drawbacks that will ultimately prevent them from fulfilling their goal of increasing health coverage for Americans and decreasing the amount Americans are paying for health care. ${ }^{78}$ These drawbacks include employers replacing low deductible plans with HDHPs but failing to contribute appropriately to HSAs; the ability of only wealthy employees to contribute their own funds to HSAs in the aforementioned situation; and younger and healthier employees' willingness to choose HDHPs with HSA addons contrasted with older, ${ }^{79}$ and unhealthier employees' desire to continue using low deductible health plans driving the cost even higher. ${ }^{80}$

Since the inception of HSAs, opponents to the program have questioned the actual cost-effectiveness of implementing such a plan. One principal argument states that the segments of society with the highest health care spending will not be affected by the implementation of HSAs. ${ }^{81}$ HSA critics state that

76 Razor, supra note 51.

77 See also Larson \& Dettman, supra note 74, at 1093-96 (explaining that many families who lack health insurance during medical emergencies suffer extreme financial difficulty by being forced to bear the cost of care); Andrews, supra note 52 (briefly examining the potential promise and setbacks that may be experienced with HSAs). But see John Torinus, Fix for Health Care Costs Rests in Hands of Consumers, THE MILWAUKEE J. SENTINEL, July 24, 2005, at D3 (advocating that the five year track record of HSAs is enough to prove CDHPs are successful in lowering health care costs).

78 See generally Kozak, supra note 57.

79 While HSAs may appeal to younger, healthier employees, it should be noted that, according to a survey published by the U.S. Bureau of Labor Statistics, in 1997 American workers ages 16-34 comprised roughly thirty-four percent of the working poor. See BUREAU OF LABOR STATISTICS, Young AdULTS MOST LIKELY TO BE AMONG THE WORKING POOR (1999), available at http://stats.bls.gov/opub/ted/1999/sept/wk2/art03.htm.

80 Kozak, supra note 57, at 60 (suggesting only the wealthy employees will be able to afford to contribute to HSAs). However, many Americans who are employed by small businesses earning nominal wages cannot afford to contribute enough to an HSA to meet the high deductible requirements. Consequently, this class of workers may continue to avoid seeking and securing health coverage. See Small Business Health Plans, supra note 16 (providing statistics illustrating that small business employees generally produce smaller incomes than employees at larger firms).

81 Razor, supra note 51, at 440. 
even if HSAs were adopted by employers across the nation, the health care industry would only experience a decline of two percent in health care costs. ${ }^{82}$ In his testimony before Congress, Robert Greenstein, the Executive Director for the Center on Budget and Policy Priorities, stated that tax savings offered by HSAs were not incentive enough for persons in the ten to fifteen percent tax brackets to purchase into a HSA. ${ }^{83}$ Thus, if HSAs cannot provide enough tax incentive for those consumers in the lower income brackets, then only the healthier, higher wage earning members of society will shift toward using the HSA model ${ }^{84}$ The subsequent effect would result in insurance companies insuring a poorer, less healthy segment of society, ${ }^{85}$ which will cause premiums to increase.

The effect of HSAs will become difficult to realize unless they are implemented on a large scale. ${ }^{86}$ By increasing the aggregate risk pool a greater degree of bargaining power would be created among patients utilizing HSAs to finance their health care needs. ${ }^{87}$ In a recent survey of member companies of the International Society of Certified Employee Benefit Specialists, ninety-six percent indicated that their companies did not offer HSAs ${ }^{88}$ When asked what the most important reason to offer HSAs to employees would be, fifty-seven percent of employers responded that the main reason to offer the plan revolved around costs. ${ }^{89}$ Ironically, despite employers' faith in HSAs to control costs, forty-nine percent were undecided when asked if they would offer HSAs as a form of health care financing to their employees. ${ }^{90}$ Although the results of this survey are by no means conclusive, they do provide a good indication of the general sentiment employers have regarding HSAs. The indication is that there is confidence among employers that HSAs will reduce costs but there nevertheless remains reluctance by employers to provide an HSA option for their employers. Without a popular movement toward implementing HSAs on a large

82 Health Savings Accounts and the New Medicare Law: The Face of Health Care's Future?: Hearing Before the Special Senate Comm. on Aging, 108th Cong. 41-56 (2004) (statement of Robert Greenstein, Executive Director, Center on Budget and Policy Priorities).

${ }^{83} I d$.

${ }^{84}$ Larson \& Dettman, supra note 74, at 1122-23 (citing an industry-wide study on the effects of CDHPs as stating that HSAs "are designed only to 'cherry pick' the young and the healthy; [they] do not adequately address the special needs of the chronically ill, acutely ill, and lower-wage employees.").

85 Spiegel, supra note 67, at 230.

${ }^{86}$ Kaplan, supra note 54, at 565. See also Small Business Health Plans, supra note 16 (stating that House Republicans passed legislation allowing small business owners to unite by associations and purchase health care at a discount, thus enabling the savings to be passed on to the consumer).

87 Id.

88 JOHN C. GARNER, INT'L SOC'Y CERTIFIED EMPLOYEE BENEFIT SPECIALISTS, PREDICTING THE FUTURE OF HEALTH SAVINGS ACCOUNTS, available at http://www.iscebs.org/PDF/HSA_survey.pdf.

${ }_{90} \bar{I}$ Id. 
scale, HSAs will remain unable to resolve the immediate health care crises facing the working poor in America.

\section{B. Access to Health Care Goods and Services}

In addition to solving the financial cost issue, it is also important to consider the implications of physical access to high quality health care. Patients living in less economically stable communities will experience the greatest difficulty physically accessing health care facilities. "[W]ith hospital construction taking place mostly in affluent areas and technology not making its way as much into hospitals in less-affluent areas, the quality of care for the poor may be falling behind."91 Not only are the poor unable to secure access to higher quality health care, but the inability to do so may result in the need for more care which will increase costs for providers and patients.

Two important factors drive consumer utilization of health care goods and services: 1) the ability to pay, and 2) the ability to gain physical access to goods and services. ${ }^{92}$ The inability to afford quality health services can often be attributed to socio-economic status. ${ }^{93}$ This is demonstrated by the fact that insurance coverage is usually tied to employment, and employers who hire low wage earners are more reluctant to offer health coverage plans. ${ }^{94}$ One problem driving health care costs higher revolves around a consumer's decision not to seek treatment because of the extreme cost of health care. A recent survey found that forty-seven percent of uninsured postponed care because it was too expensive and thirty-seven percent did not fill prescriptions because the cost of medicine was too high. ${ }^{95}$ The access problems created by HSAs are created by the high deductible requirement and the necessity of accumulating funds in order to realize the benefits of the accounts. ${ }^{96}$ The effect is that patients will often avoid necessary medical care in an attempt to accumulate funds or to avoid paying the high deductibles. As a result it is highly probable that the severity of their condition will worsen, and more expensive advanced care will be required to treat the ailment.

Cost reduction is an imperative step toward securing access to health care for Americans unable to afford such care. Often times, impoverished Ameri-

91 Joesph Mantone, Incentives Linked to Access Woes, MODERN HEALTH CARE, Dec. 12, 2005, at 10 .

92 Anita Pereira, Note, Live and Let Live: Health care is a Fundamental Human Right, 3 CONN. PUB. INT. L.J. 481, 487 (2004).

93 Henry J. Kaiser Fam. Found., The Kaiser COMmission on MEdicaid and the Uninsured: The Uninsured AND TheIr ACCess to Health CARE (2003), available at http://www.kff.org/uninsured/loader.cfm?url=/commonspot/security/getfile.cfm\&PageID=29284

${ }_{94}$ Pereira, supra note 92, at 483-84.

95 Id. This survey also noted that thirty-six percent of the uninsured had difficulty in paying their medical expenses and twenty-three percent were contacted by a collection agency about medical related expenses.

96 Larson \& Dettman, supra note 74, at 1112. 
cans face lifestyle problems such as poor nutrition and unsanitary living conditions ${ }^{97}$ and are unable to afford health care that may help them change these lifestyles. Access to health care would increase public knowledge about the correlation between poor nutrition and unsanitary living conditions and health concerns. Furthermore, the working poor are often employed in "low-wage jobs working for small employers in the retail or service industry." "98 These types of employers generally offer fewer health benefits than their larger counterparts. ${ }^{99}$ Moreover, the working poor ${ }^{100}$ who are employed at several parttime jobs experience roughly four times less access to health care benefits than they would if they worked one full time job. ${ }^{101}$ Lack of education and marketable job skills, however, are often associated with the impoverished classes, and as a result, securing a full-time job that offers health care benefits may be more difficult.

These unhealthy employees will have higher health care expenditures and will likely be dissuaded from HSAs because they will not have the opportunity to accumulate any funds in their account. ${ }^{102}$ But according to some proponents, "the tax-free payment of expenses and lower insurance premiums" may provide enough of a benefit to act as an incentive. ${ }^{103}$ The "working poor" in America,

97 Walter L. Stiehm, Poverty Law: Access to Healthcare and Barriers to the Poor, 4 QUinNipiac Health L.J. 279, 279 (2001). See also Richard EPSTEIN, MORAL PerIL: OUR INALIENABle Right to Health CARE? 112-13 (Addison-Wesley Publ'g Co., Inc., 1997) (explaining that the solution to solving America's inability to provide universal health coverage is not going to be found in consumer driven plans; rather, it will require changes that equalize the opportunities of life across America's population).

98 Stiehm, supra note 97 , at 287.

99 According to a National Compensation Survey conducted by the United States Bureau of Labor Statistics, establishments with under one hundred workers offered medical benefits, on average, to fifty-nine percent of their employees. Goods producing establishments offered medical benefits to eighty-five percent of their employees while service producing establishments offered medical benefits to only sixty-six percent of their workers. As of March 2005, part-time employees in America's private industry realized medical benefits only twenty-two percent of the time compared to full time employees who received medical benefits $85 \%$ of the time. U.S. Bureau of Labor Statistics, National COMPENSATION SURVEY: EMPlOYEe BeNEFITS IN PRIVATE INDUSTRY IN THE UNITED STATES (2005), available at http://stats.bls.gov/ncs/ebs/sp/ebsm0003.pdf.

100 The term "working poor" is defined by the United States Department of Labor as "individuals who spent at least 27 weeks in the labor force (working or looking for work), but whose incomes fell below the official poverty level.” U.S. DEPT. OF LABOR, A PROFILE OF THE WORKING POOR 2000 (2002), available at http://www.bls.gov/cps/cpswp2000.htm.

101 U.S. BUREAU OF LABOR STATISTICS, supra note 99. See also Kaplan, supra note 54, at 543 ( " $[\mathrm{I}] \mathrm{n}$ an employment-based health insurance system, the loss of one's job seriously jeopardizes a person's access to health insurance.").

102 See Daniel Lublin Pollock \& Natalie E. Ranier, Sixth Annual Review of Gender and Sexuality Law: VI Health Care Law Chapter: Health Care Access: A Review of Major Barriers to Health care Services for Women, 6 GEO. J. GENDER \& L. 825, 845 (2005). See Spiegel, supra note 67, at 231-32 (questioning the effectiveness of HSAs to decrease health care related expenditures).

${ }^{103}$ [I]t may be impossible to accumulate an HSA account balance if medical 
those who earn too much to obtain government help and too little to afford quality health care, ${ }^{104}$ however, may not have the opportunity to contribute to HSAs in a manner significant to take advantage of the aforementioned benefits. ${ }^{105}$ This may be because their wages are being used to finance other living expenses or continuously being applied to the high deductibles that HSAs require.

A recent survey illustrates the inability of HSAs and HDHPs to resolve the immediate need to provide broad health coverage to the nation's low wage earners, including those employed by small business owners. ${ }^{106}$ The survey reported "[h]ealth insurance premiums for a family of four now average almost $\$ 11,000$ a year." 107 The reason why small and large firms that employ large numbers of low wage earners are reluctant to offer health care plan benefits ${ }^{108}$ is because the cost of providing health care is more than these employees are earning, ${ }^{109}$ thus placing a larger burden on the employer. Current health insurance premiums would consume the entire salary of the nation's lowest wage earner for one year. ${ }^{110}$ As a result, Americans with moderate to low incomes may not

expenses are high each year, thereby eliminating the tax-free growth potential. But the tax-free payment of the expenses and lower insurance premiums that are paid by the insured may prove to be enough of a benefit. Also, those who have a long-term disability would have to exhaust their deductible every year. Once again, those with long-term illnesses would need to evaluate how the plan would effect them.

McCall, supra note 57, at 60.

104 Stiehm, supra note 97, at 285.

105 Kozak, supra note 57, at 60.

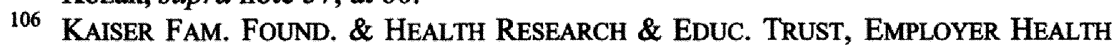
BENEFITS: 2005 SUMMARY OF FINDINGS (2005), available at http://www.kff.org/insurance/7315/sections/upload/7316.pdf.

107 Id. See also Arnold S. Relman, Reforming the U.S. Health Care System: What the Legal \& Medical Professions Need to Know, 15 HEALTH MATRIX 423, 429-30 (2005) (explaining that impoverished Americans in CDHPs face a choice of either spending money in their account or not getting the care they need and proposes that a single insurance system funded by corporate tax contributions could resolve the problem).

108 KAISER FAM. Found. \& HEALTH RESEARCH \& Educ. TRUST, supra note 106. See Christopher Rowland, 5-7\% Tax Sought On Firms For Health care, THE Boston GLOBE, Nov. 1, 2005, at A1 (discussing a plan unveiled by the Massachusetts House Speaker, Salvatore F. DiMasi, to levy a five to seven percent payroll tax on employers in Massachusetts who did not provide health insurance to employees).

109 Determinations of persons qualifying for Medicare are made on an objective case-bycase basis based upon available income. If employees do not qualify, they become dependent on their employers for health care benefits, and unfortunately, many small businesses do not offer such benefits because they are too expensive. See 45 C.F.R. $\$ 233.20$ (a)(1)(iv)(D) (1994) ("To the extent not inconsistent with any other provision of this chapter, income and resources are considered available both when actually available and when the applicant or recipient has a legal interest in a liquidated sum and has the legal ability to make such sum available for support and maintenance.").

110 KaISER FAM. FOUND. \& HEALTH RESEARCH \& EDUC. TRUST, supra note 106 ("Gross earnings for someone earning the federal minimum wage in 2005 and working 2,080 hours are $\$ 10,712$."). 
have access to quality health care or, for that matter, any health care at all. ${ }^{111}$

Access to health care should not be an issue for Americans. Health care is an indispensable service that those living in one of the most affluent countries in the world ought to be able to enjoy without having to worry about how to finance their own care. If Congress begins to shift its focus toward broad health care access perhaps legislators will begin to realize the importance of providing health care to American citizens, which would awaken legislators to the reality that Americans need affordable health care. Without equal access among all working citizens, unemployed, and indigent some argue that health care will never be recognized as the fundamental right it is. ${ }^{112}$ One proponent of heath care access as a fundamental human right categorized accessibility as having four distinct, overlapping elements. ${ }^{113}$

The first step in providing equal access to health care is making providers implement non-discriminatory practices. ${ }^{114}$ This means that unfettered access to the nation's best health care providers must be granted to all people regardless of gender, race, and socio-economic status. ${ }^{115}$ Currently, the socioeconomic barriers in America are not allowing this to occur. The implementation of HSAs will only exacerbate this problem among the lower socioeconomic classes because as previously mentioned, one of the flaws surrounding HSAs is the inability of the indigent to meet the required deductibles. ${ }^{116}$

The second element of accessibility concerns one's physical ability to get to health care facilities. ${ }^{117}$ This means that adequate health care should be "within safe physical reach for all sections of the population, especially vulnerable or marginalized groups."118

The third and fourth prerequisites for better system accessibility involve economic and information accessibility. ${ }^{119}$ This simply means that all aspects of the population should be able to experience quality health care at an affordable price. Moreover, the entire population should have access to adequate in-

111 Contra Mary Anne Bobinski, Health Disparities in Health Care: Wrongs in Search of a Right, 29 AM. J.L. \& MED. 363, 365-66 (2003) (suggesting that socio-economic factors are not the sole reason that there is unequal access to health care and also attributing the inequity of access to health care goods and services to race and gender); EPSTEIN, supra note 97, at 112-13 (explaining that the solution to solving America's inability to provide universal health coverage is not going to be found in consumer driven plans, rather it will require changes that equalize the opportunities of life across America's population).

112 Pereira, supra note 92, at 481-90.

113 Id. at 487.

114 Id.

115 Id.

116 Kozak, supra note 57, at 60.

117 Pereira, supra note 92, at 488 ("Accessibility also implies that medical services and underlying determinants of health, such as safe and potable water and adequate sanitation facilities, are within safe physical reach, including in rural areas. Accessibility further includes adequate access to buildings for persons with disabilities.").

118 Id. at 487.

119 Id. at 488. 
formation and the necessary means to process that information effectively readily available to assist in making health care consumption decisions. The primary role of HSAs would be to fulfill the third and fourth categories but would likely do little to address the non-discrimination and physical access requirements for equal access. Hence, even portions of the population outside of small business employment are unable to secure health care under the current HSA plans that promote a market-based solution.

If HSAs were intended, at least in part, to reduce health related expenses in this new era of rapidly advancing technology, while likewise, increasing access to the American health care system for all, then HSAs have not yet succeeded. Too many problems remain regarding how to handle chronic illness, elderly care, and impoverished Americans' inability to afford care.

\section{SMALL BUSINESSES AND THE UNINSURED: STRUGGLES WITH HSAS}

America's low-wage earners tend to work for employers who do not provide health insurance coverage. "Typically, the uninsured are unemployed, self-employed, work for small businesses, or work part time." ${ }^{\text {120 }}$ The majority of the American work force is employed by companies with less than fifty employees. ${ }^{121}$ This statistic reflects the propensity of small companies to hesitate in introducing health insurance plans to their employees due to cost. ${ }^{122}$ The introduction of HSAs, however, will purportedly allow reluctant employers to pass more of the health insurance costs on to their employees. ${ }^{123}$ Furthermore, HSAs actually create an incentive precisely to encourage this type of burden shifting, ${ }^{124}$ which is the result that society wants to avoid. Costs should not be placed on the shoulders of employees because often times those employees do not have sufficient resources to carry that burden. The question remains, then, as to exactly how effective HSAs will be in reducing costs and increasing access and quality within the health care industry.

While the potential of HSAs has been hailed since the passage of the MMA, employees of small American businesses have not yet been able to reap the benefits HSAs promised to provide. Among those small firms, with less

120 Larson \& Dettman, supra note 74, at 1106.

121 LYKE, PETERSON \& RANADE, supra note 4.

122 Id.

123 See Spiegel, supra note 67, at 235-36 (arguing that while HSAs implemented in the context of a large employer will tend to shift costs onto the employees, their implementation in the context of small businesses is likely to succeed).

${ }^{124}$ LYKE, PETERSON \& RANADE, supra note 4 ("Small employers may also find HSA accounts attractive since they would obtain employment tax savings on employee contributions that are made through salary reductions."). See also H.R. 1872, 109th Cong. (1st Sess. 2005) (Proposed by Texas Congressman, Sam Johnson, the Health Coverage for the Uninsured Act of 2005, among other things, would amend the Internal Revenue Code to allow employers of less than 100 employees a refundable tax credit for contributions to a health savings account of employees covered by high deductible health plans.). 
than two-hundred employees, only twenty percent offered some type of HDHP. ${ }^{125}$ More indicative of a small firm's propensity to balk at instituting HSAs are data illustrating that only two and three-tenths percent of all firms offering health benefits actually offer an HSA qualified HDHP. ${ }^{126}$ So even if HSAs functionally meet their expectations, their lack of popularity will not effectuate a change in the health care market in the near future. Typically, those lacking health insurance in America tend to be either "young adults, poor, Hispanic, or employees in small firms."127 Further, while these are distinctive characteristics of individuals lacking health insurance, they are not always exclusive of each other.

The urgency for a solution addressing the availability of health insurance to young, moderate wage earners employed by small businesses is of utmost importance. Proponents of HSAs as a solution to small business health insurance problems suggest that HSAs combined with a HDHP "lowers the insurance rates for an employer, allowing small businesses to fit health insurance into their budgets." "I28 In a radio address to the nation, President Bush echoed this sentiment when he stated, "[a] new product known as Health Savings Accounts helps control costs by allowing businesses or workers to buy low-cost insurance policies for catastrophic events and then save, tax-free, for routine medical expenses." 129 Critics of HSAs, however, suggest that this form of health coverage will only appeal to the affluent, healthy workers seeking to take advantage of tax shelter benefits. ${ }^{130}$ This is because persons who fit into this category likely do not wish to expend their financial resources on traditional insurance due to their underutilization of the services for which they are paying. When individuals contribute their own financial resources to the account, they are more likely to obtain medical goods and services only when truly needed.

125 KAISER FAM. Found. \& HEALTH RESEARCH \& EdUC. TRUST, supra note 106. The statistics from the survey reflect a ten percent increase among small firms offering an HDHP in 2005. The survey notes, however, that this increase may be attributed to the evolving definition of HDHPs.

126 Id.

127 Chris L. Peterson, Cong. Research Serv., Health Insurance Coverage: CHARACTERISTICS OF THE UNINSURED AND UNINSURED POPULATIONS IN 2001 (Jan. 7, 2003), available at http://www.law.umaryland.edu/marshall/crsreports/crsdocuments/96-891 EPW.pdf. Specifically, persons between the ages of nineteen and thirty-four comprise thirtyfour percent of the uninsured population. Furthermore, fifty-one and nine tenths percent of the uninsured population is employed by firms with fewer than one hundred workers.

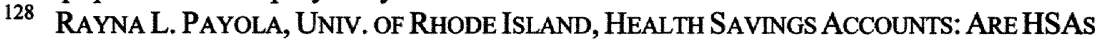
BENEFICIAL FROM THE EMPLOYEE's VIEW? ARE HSAS BENEFICIAL FROM THE EMPLOYER'S VIEW? (2005), available at www.uri.edu/research-/lrc/Papers/Paola_HSA.pdf (2005).

${ }_{129}$ President George W. Bush, Radio Address, Economy and Small Business (Jan. 21, 2006), available at $\mathrm{http} / / / \mathrm{www} . w h i t e h o u s e . g o v /$ news/releases/2006/01/20060121.html.

130 EDWIn Park \& Robert GreEnSteIn, CTr. Budget \& Pol'y Priorities, Latest

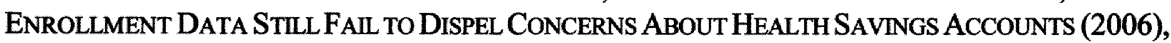
available at $\mathrm{http} / / / \mathrm{www} . \mathrm{cbpp} .0 \mathrm{rg} / 10-26-05 \mathrm{health} 2 . \mathrm{htm} \#$ ftnref5; see also Spiegel, supra note 67, at 230; Peter G. Gosselin, Health Plan to Revive Debate, L.A. TIMES, Jan. 23, 2006, at A1. 
Furthermore, rather than contributing finances to traditional health insurance models, HSAs allow one to contribute and use funds in the account tax-free, which is appealing to young workers.

Because HDHPs appeal primarily to the healthier, more affluent workers, it has been suggested that "the average cost of insuring any given risk pool will increase, likely causing both premiums and overall health care expenditures to rise dramatically." 131 In other words, the "health demographics" ${ }^{, 12}$ of risk pools will dramatically shift, thereby leaving the poor, sick, and otherwise unhealthy to be insured by their respective insurers. As a result of the inability to spread the costs of this risk among the healthy and ill alike, the costs of insurance will increase. The fallout from such a shift would likely fall heaviest upon the middle to lower income financial brackets already experiencing difficulty in financing their health care.

Also problematic, and perhaps disheartening, is the fact that many insured families are facing bankruptcy more often than their uninsured counterparts as the result of catastrophic illnesses. ${ }^{133}$ Often times the associated medical expenses are well below the catastrophic minimums required by HDHPs. ${ }^{134}$ If insured families are facing difficulty in financing catastrophic illnesses, uninsured families are at an even greater risk for financial instability. This presents yet another problem with regard to maintaining costs and increasing access to care. Uninsured families may be granted access to care in the event of a catastrophic accident or illness, but the costs of the care will be redistributed. ${ }^{135}$ In this scenario, the family will likely be forced into bankruptcy and costs for the uninsured's inability to pay will be passed along by the providers to other patients in the form of higher health care costs. ${ }^{136}$ Bankruptcy reform proponents ${ }^{137}$ have suggested confronting this dilemma by "providing unconditional

131 Spiegel, supra note 67, at 230. See also Editorial, The Lopsided Bush Health Plan, N.Y. TIMES, Feb. 3, 2006, at A22 (warning of the potential dangers if healthy employees all jump to HDHPs).

132 The term "health demographics" is used here to describe the make up of a particular risk pool. For example, the health demographics of a young, affluent, risk pool are going to reflect a healthier population as opposed to an older, poorer risk pool that will likely reflect greater occurrences of illness in the health demographics. See Spiegel, supra note 67, at 230 (discussing how adverse selection will likely negatively affect the average cost of insuring a respective risk pool).

133 Larson \& Dettman, supra note 74, at 1121 (citing David U. Himmelstein et al., Illness and Injury as Contributors to Bankruptcy, HEALTH AFF. WEB EXCLUSIVE, at W5-63, W5-66, Feb. 2, 2005).

134 Id.

135 Id. (Medical related spending in the year that families experienced catastrophic illness nearly quadrupled from the previous year. "[Researchers] explained, 'in the year prior to bankruptcy, out-of-pocket costs (excluding insurance premiums) averaged $\$ 3,686$. ... Out-of-pocket costs since the onset of illness/injury averaged $\$ 11,854$."').

136 Id.

137 Id. This suggested bankruptcy reform proposal seems to be antithetical to the premise behind HSAs of encouraging fiscal responsibility. Id. 
debt relief to individuals who legitimately use bankruptcy as insurance of last resort in the aftermath of serious calamities." 138 While this may alleviate the immediate problems of the uninsured family, this solution does nothing to resolve the issues of access and increased cost for the working poor population as a whole. Providers are still going to pass the costs on to future patients, and these high costs are likely to dissuade the uninsured from seeking treatment.

As the burgeoning American population continues to grow, ${ }^{139}$ it is important to focus resources on and tailor solutions to this targeted area of health care consumers so that the problems of inadequate access for America's moderate to lower income brackets may be halted in its infancy. Without a solution specifically tailored to address the lower income segments of the population, health care availability in America will remain stagnant and may begin to decline with the continued adherence to the HSA model within the context of small businesses.

\section{PROMISING Alternative Solutions to THE High Costs of HEALTH CARE}

There have been many suggestions concerning how to remedy the pending health care crisis in America. Most notably and widely advocated, is the push toward a government regulated health care system ${ }^{140}$ consistent with that of most other developed nations. ${ }^{141}$ Because of most Americans' reluctance to subscribe to a universal health care approach, the preferred method seems to be an incremental approach attempting to fix aspects of the system piece by piece;

138 Melissa B. Jacoby, Collecting Debts from the Ill and Injured: The Rhetorical Significance, but Practical Irrelevance, of Culpability and Ability to Pay, 51 AM. U.L. REV. 229, 231 (2001).

139 The United States Census Bureau estimated that the population in America grew by an estimated 2,753,562 persons from July 1, 2004 to July 1, 2005. Natural birth increased the population by $1,704,036$ and international documented immigration grew the population by 1,049,526. U.S. Census Bureau, Population Division, TABLE 5: ANNUAL Estimates of THE COMPONENTS OF POPUlation Change for the UNITED STATES AND STATES: JUly 1, 2004 to JULY 1, 2005 (2005), available at http:/www.census.gov/popest/states/tables/NST-EST200505.xls.

140 See Hampton, America's Flight from Health Insurance, supra note 1 (suggesting that Americans should not subscribe to the myth that the health care market will allocate resources more efficiently than the government); Jacobi, Government Reinsurance, supra note 10 (advocating that the government assume catastrophic coverage costs and leave nominal health costs to consumers).

${ }^{141}$ See Pereira, supra note 92, at 501 (suggesting that universal coverage is not the only answer to solving access problems within the United States; rather, simply recognizing health care as a fundamental human right and eliminating poverty is the first step toward increasing access problems). Pereira's argument seems a bit overly ambitious within a capitalistic society of which poverty is an inherent part. A true solution would maintain the spirit of capitalism outside of the health care marketplace and place the regulation of this marketplace under government control. Eliminating poverty is a noble undertaking but may be too complex of a solution to increasing access to health care. 
such an approach has been deemed to be inefficient. The problem with this idea is not only the amount of time it takes to implement the new plan, but more importantly, the amount of time that must pass before results of the new system can be realized. For example, HSAs have been implemented for almost three years at this point, yet only two and three tenths percent of employers ${ }^{142}$ are offering them as a solution to health care benefits.

Therefore, a non-incremental solution to the federal government's continuing piecemeal approach may be in order. Short of a complete transition to universal health care, there are several other possibilities that may help remedy the access and cost problems facing America's working poor. Among these solutions are greater emphasis placed on consumer education, organization of consumer factions to effectuate change on a larger scale, and President Bush's Association Health Plans. ${ }^{143}$

\section{A. Consumer Education}

In order for consumers to make educated purchasing decisions, a greater emphasis must be placed on the importance of providing adequate information that addresses how to avoid underfunding HSAs, illustrates provider performance information, ${ }^{144}$ discloses costs of medical goods and services, ${ }^{145}$ coaches consumers on how to judge the quality of health care, ${ }^{146}$ and informs consumers as to how this information applies to HSA and their accompanying HDHP. The idea behind providing consumers with more information is to make them more powerful yet prudent consumers of health care goods and services. Access to high quality information creates individual bargaining power, especially if one can analyze that information appropriately and is willing and able to use it. ${ }^{147}$

Legislation mandating the standards of information disclosure centering on the health care industry should be enacted. Possible legislation may include mandating the completion of some type of educational program illustrating to consumers how to interpret complex information provided by the health care

142 KaISER FAM. Found. \& HeAlth ReSEARCH \& Educ. TRUst, supra note 106.

143 U.S. Chamber of Commerce, Small Business Health Plans, http://www.uschamber.com/issues/index/health/ahps.htm (last visited Mar. 25, 2007).

${ }^{144}$ Kate Sullivan, Dir. Health Care Pol'y, U.S. Chamber of Commerce, Testimony before the United States House of Representatives Small Business Subcommittee on Workforce, Empowerment, and Government Programs: The Benefits of Health Savings Accounts (Mar. 18, 2004), available at http://www.uschamber.com/NR/rdonlyres/exwu6pctkeizcdxqr4vmfgoise3cqvitakllg4urmp4pc22yobfc34fsjpw3qrorgena5pevp 7wa4m/HealthSavingsAccountsMarch 1820040 .pdf\#search='Health $\% 20$ Savings\%20accounts $\% 20$ small $\% 20$ employers $\% 2$ 0affluent'. See also HERZLINGER, supra note 42; Mariner, supra note 30, at 514-17 (suggesting that even with complete information disclosure, this may still be insufficient to meet consumer needs and promote cost efficient consumption).

145 Sullivan, supra note 144.

146 Jacobson, supra note 27, at 391.

147 Barnhizer, supra note 12, at 167. 
industry. This type of information is essential to successfully managing the recently opened HSA internet-based courses that are a possible solution for the nation's younger generations because of the ease of access and familiarity this segment of the population has with the World Wide Web. Even if one does not have private access to a web-based learning program, many public libraries across the nation ${ }^{148}$ offer free access to the World Wide Web where the programs could be completed. For those without internet access, traditional community learning courses could be offered at local churches, schools, or community centers addressing the same topics covered by the internet courses. Furthermore, when drafting legislation to implement information disclosure programs, Congress should consider the consuming public, rather than health care experts and competing health care providers, as the primary audiences of any disclosed information pertinent to CDHPs. ${ }^{149}$ The objective of this type of mandate would be to consolidate information into easily translatable information that is the most relevant to key consumer decisions.

An increase in the availability of a web-based learning system would allow easier access for the entire gamut of American society. If Congress were to mandate the passage of these web-based learning courses, then America could rest assured that best efforts had been made to inform the consuming public about the types of decisions involved with managing a HSA. Informed consumers are prudent consumers able to allocate financial resources efficiently. If implemented successfully and adopted by consumers, this may help bolster the argument that market forces will be able to succeed in reducing costs associated with health care. ${ }^{150}$

\section{B. Organized Consumer Bargaining Factions}

Individual consumers lack the requisite bargaining power necessary to effectuate a transformation in American health care costs. If a large population of Americans could organize into consumer bargaining factions, this may help increase their bargaining power as a united class. Price is a contractual term

148 As of 2004, over ninety-five percent of America's public libraries offered internet access. Furthermore, families earning less than fifteen thousand dollars per year were two to three times more likely to use public internet access at these locations than were families earning over seventy-five thousand dollars per year. Public Libraries Boost Internet Access, Early Literacy, USA TODAY, Feb. 6, 2004, available at $\mathrm{http}: / \mathrm{www}$.usatoday.com/news/education/200402-26-librarian-convention_x.htm.

149 But cf. William $\bar{M}$. Sage, Regulating Through Information: Disclosure Laws and American Health Care, 99 CoLUM. L. REv. 1701, 1792 (1999) (suggesting that in the context of managed care, in order to improve productive efficiency, the consumers are "not the most meaningful audience").

${ }^{150}$ But cf. Hampton, America's Flight from Health Insurance, supra note 1 (suggesting that health care provisions are better left to the federal government than to traditional market forces). 
particularly subject to negotiation. ${ }^{151}$ Consequently, if the working poor in America can mobilize and present themselves as a unified group to health care providers, they may be able to effectuate a change in health care pricing.

In order to do this, it will be necessary for the consumer faction to illustrate that its members are prudent, informed consumers capable of making efficient purchasing decisions. "As a practical matter, poor individuals often do lack bargaining power - the power to obtain a preferred outcome in a transaction. . . ."152 If these individuals are able to organize on a large scale into consumer factions, however, it is likely that health care providers will recognize the purchasing power of these factions as they relate to necessary medical expenses. On the other hand, this type of recognition may arise naturally if the market within the health care industry functions efficiently.

The idea behind organizing consumers into collective groups is based on the theory that those consumers joining the faction will be responsible, prudent consumers as a result of the education they received from the previous proposition for a mandated web-based HSA educational program. Moreover, these consumer factions will be unsuccessful unless they are implemented on a large scale. Their ability to influence depends heavily on the number of consumers for whom these factions will be negotiating. With the ability to organize, poorer employees, as individuals, will gain a considerable amount of bargaining power through these factions that may help them obtain the ability to negotiate end prices more effectively within the health care market.

\section{Health Security for All Americans Act}

In May of 2005, members of the House of Representatives took the goal of obtaining affordable, high quality health care a giant leap farther when nineteen representatives introduced into the House, the Health Security for All Americans Act. ${ }^{153}$ The Health Security for All Americans Act ("HSAAA") establishes as its goal "[t]o guarantee for all Americans quality, affordable, and comprehensive health insurance coverage." ${ }^{\prime 54}$ The HSAAA purports to accom-

151 Barnhizer, supra note 12, at 212.

152 Id. at 152.

153 Health Security for All Americans Act, H.R. 2133, 109th Cong. (2005). The Health Security for All Americans Act is similar to the Health Security Act proposed by former President Bill Clinton in 1993 which failed largely because it lacked the requisite backing of Congress and the American public, but its failure has also been attributed to the complexity of the legislation. See Linda M. Harrington, Health Care Reform vs. Pet Goals; In Congress, Illinoisians Mostly Aiming for Crime Bills, CHI. TRIB., Jan. 22, 1994, at N1; Amy Goldstein \& Terry M. Neal, On the Road, Away From Crises; Clinton's Pitch on Health Care Reflects Lessons Learned in '94, WASH. PosT, Aug. 11, 1998, at A1 (stating that former President Clinton's health care reform platform was short lived, losing momentum and dying only one year after it was first introduced).

154 H.R. 2133, 109th Cong. (2005). See also Press Release, Baldwin Announces Legislation to Cover the Uninsured (May 10, 2004), available at 
plish this proposition by implementing its requirements in two phases.

The first phase involves implementing voluntary state plans ${ }^{155}$ as a test run. The voluntary state plan phase asks participating states to establish systems that are responsible for ensuring universal coverage within the state, and provides for federal funding to states participating in the program. ${ }^{156}$ For the second phase, the HSAAA calls for the mandatory implementation of state plans. ${ }^{157}$ Under the HSAAA, states are required to submit to the Secretary a plan breaking down how that particular state intends to use the federal funds to establish a universal health care program within their jurisdiction. ${ }^{158}$

The HSAAA arose in light of congressional findings regarding the status of health care costs and how these costs relate to public consumption. Among these findings include statistics that indicate personal spending on health care is growing two and five-tenths percent faster than the gross domestic product of the country. ${ }^{159}$ Moreover, Americans are paying two times as much for health care than they were a decade ago, ${ }^{160}$ and health care administrative costs per person are more than five times greater than other industrialized countries that have implemented a universal health care plan. ${ }^{161}$ In other words, health care costs are substantially higher and are continuing to grow at a rapid rate due to the reluctance of Americans to embrace a universal health care system similar to the one suggested by Congresswoman Tammy Baldwin.

One downfall of the HSAAA is that it does not set forth from where the source of government financing will come. Surely, Congresswoman Baldwin did not intend the HSAAA to cover all related medical expenses, including non-essential costs. As one critic commented, "someone must establish a limit on which services are and are not covered in any government subsidized health care program. The issue becomes one of who will set the limits and what those limits will be."162 Congresswoman Baldwin's answer seems to point toward the states as being responsible for implementing fifty separate universal health care systems unique to the needs of each state. ${ }^{163}$ Although, on its face, the HSAAA seems to gravitate toward a universal solution, as a practical matter it is not likely to succeed. This is largely because in its application, the bill is just an-

http://tammybaldwin.house.gov/PRArticle.aspx?NewsID=373 [hereinafter Baldwin Announces Legislation to Cover the Uninsured] (Congresswoman Baldwin's website reports that "[ $t$ ]he bill will secure health insurance for all Americans, guarantee affordable health care by limiting outof-pocket expenditures, provide comprehensive health care by guaranteeing a minimum benefit package equal to the benefits offered to Members of Congress, and ensure the quality of health care by providing strong patient protections.").

155 H.R. 2133, 109th Cong. (2005).

156 H.R. $2133 \S 2201(\mathrm{~b})(1)-(2), 109$ th Cong. (2005).

157 Id. $\$ 2211(\mathrm{a})(1)-(2)$.

158 Id. $\S 2211$.

159 Id. $\S 2(8)$.

160 Id. $\S 2(12)$.

161 See id. \$2(14).

162 Stiehm, supra note 97, at 291.

163 See H.R. 2133, § 2211(a)(1), 109th Cong. (2005). See also Baldwin Announces Legislation to Cover the Uninsured, supra note 154. 
other piecemeal attempt toward universal health care that is genuinely federally regulated. The problem with HSAAA as written may be that it allows too much subjectivity on the part of each individual state's legislature. Universal health care benefits would fluctuate from state to state based on their interpretation of what medical goods and services should be covered.

Thus, the Health Security for All Americans Act is a good solution on its face but is not likely to succeed in its goal of providing universal coverage. In order to accomplish this, the HSAAA should be redrafted to make health care regulation a "true" function of the federal government rather than leaving regulation and implementation on the states' shoulders and placing the financial burden on the federal government. To secure an immediate solution to rising health care costs and obtain universal health care in the United States, it is necessary to make regulating, implementing, and financing the health care industry a job for the United States government.

\section{Association Health Plans (Small Business Health Plans)}

In a radio address to the nation, President Bush spoke about HSAs as a potential solution to controlling cost and increasing access to health care in America. ${ }^{164}$ The text of the address illustrates that America's leadership recognizes the deficiency that exists between small businesses versus large corporations with respect to financing health care costs.

For the sake of America's small businesses, workers, and families, we must also make health care more affordable and accessible. A new product known as Health Savings Accounts helps control costs by allowing businesses or workers to buy low-cost insurance policies for catastrophic events and then save, tax-free, for routine medical expenses. This year, I will ask Congress to take steps to make these accounts more available, more affordable, and more portable. Congress also needs to pass Association Health Plans, which allow small businesses across the country to join together and pool risk so they can buy insurance at the same discounts big companies get. ${ }^{165}$

The Association Health Plans ("AHPs") proposed by President Bush take on a function similar to that of the aforementioned consumer factions. The idea behind AHPs is to group small businesses together in order to increase bargain- 
ing power when negotiating with insurance companies for lower prices. ${ }^{166}$ In addition, AHPs will allow small business owners to expand business, share risk with other small businesses, and provide benefits for employees. ${ }^{167}$

According to the United States Chamber of Commerce, the introduction of AHPs would increase coverage by roughly eight and a half million Americans. ${ }^{168}$ Therefore, AHPs that are introduced in conjunction with HSAs may provide America with its first piecemeal victory toward increasing access, quality, and affordability to America's working poor and small businesses. President Bush traveled one step closer in implementing these AHPs and bringing health care to eight and half million Americans after the successful passage of the Small Business Health and Fairness Act of 2005 ("SBHFA") last July. ${ }^{169}$ The SBHFA sets forth the rules governing AHPs ${ }^{170}$ and the various participation and coverage requirements. ${ }^{171}$

Despite the promise of AHPs as a path to improving health care access, affordability, and cost for small businesses and their employees, critics still suggest that AHPs will "destabilize the insurance market, leading to higher premiums for small businesses that do not join association health plans."172 Some critics who disfavor the plan suggest that it will open the door to insurance scams, and more importantly that AHPs "would be largely exempt from state regulation and would attract healthier workers, "thereby increasing costs for firms that remain in the traditional insurance market." "173 Yet, in spite of this opposition surrounding AHPs, there remains a great deal of support backing their implementation. ${ }^{174}$

166 Office of the Press Sec., America's Ownership Society: Expanding Opportunities (Aug. 9, 2004), available at http://www.whitehouse.gov/news/releases/2004/08/200408099.html.

167 George W. Bush, President of the United States, Remarks by the President in a Conversation on Health Access (Mar. 16, 2004), available at http://whitehouse.gov/news/releases /2004/03/20040316-5.html. President Bush was careful, however, to instruct the audience that he was not suggesting AHPs were a directional shift toward the government assuming health care regulation responsibility when he stated, "... the option, by the way, is not to say, the federal government ought to take it over, take over the health care industry. That would be the absolute wrong prescription. The right prescription is reasonable policy, one of which is associated health plans." Id.

168 U.S. Chamber of Commerce, Just the Facts: SMAll Business Health Plans (2006), available at $\mathrm{http}: / / \mathrm{www} . u s c h a m b e r . c o m / i s s u e s /$ index/health/0306_ahps_facts.htm.

169 Small Business Health \& Fairness Act of 2005, H.R. 525, 109th Cong. (2005).

170 H.R. 525, § 801, 109th Cong. (2005).

171 Id. $\S \S 804-807$.

172 Robert Pear, Bush Prepares Health Plan Aimed at Small Businesses, N.Y. TimEs, Jan. 27, 2003, at A21.

${ }_{173}$ Robert Pear, Republicans Shift Focus to Helping the Uninsured, N.Y. TIMES, Dec. 15, 2003, at A25.

${ }_{174}$ See Memorandum from Senators Olympia Snowe, Jim Talent, John McCain, Christopher Bond, Norm Coleman, Kay Hutchinson, Elizabeth Dole, \& Arlen Specter, Senators, to The United States Senate, USA Today Supports Association Health Plans (Jan. 27, 2004), available at http://sbc.senate.gov/HTML/colleague/usatodayahpdearcolleague.pdf (suggesting that the 
In the context of segmented legislation attempting to remedy the health care crises small businesses and their employers are facing, the movement toward adopting AHPs may provide an immediate solution. Allowing small business to purchase insurance collectively will increase the bargaining power among small businesses and their employers and may help to effectuate an immediate reduction in the costs of health care. Once small businesses are able to increase their bargaining power through AHPs by purchasing collective insurance, the likelihood of increasing quality and access to health care through the implementation of HSAs appears to become more of a reality.

\section{CONCLUSION}

Managed care leaves much to be desired with respect to the various costs and tactics used to corral the health care industry's excessive costs. HSAs were thus created by President Bush with the hopes of turning over to the market the task of creating competition, and in turn, lowering the costs of care to consumers. Specifically, HSAs were aimed at lowering the cost to small businesses of providing health care benefits to their employees.

HSAs, however, present several problems when they are implemented in the context of small businesses. The nature of HSAs, principally the associated HDHPs, makes it difficult for low-wage earning employees to accumulate funds for future medical expenses. Legislation that mandates consumer education programs that shows consumers how to access, analyze, and apply health care information is a strong beginning toward allowing consumers to manage their own health care finances; however, it is an insufficient solution standing alone. Organized consumer bargaining factions could help to increase purchasing power among small businesses by illustrating to the health care industry that there is a fraction of the population whose financial resources are not effectively being utilized within the health care market.

Legislation calling for a complete government take over of the health care industry, such as the Health Security for All Americans Act, would likely provide an end-all solution to the problem, but such legislation is not likely to pass because incremental solutions seem to be a preferable solution among Con-

attached USA Today editorial accurately frames the debate surrounding AHPs); Letter from Olympia Snowe, Senator, to William Frist, Senate Majority Leader (Feb. 16, 2006), available at http://sbc.senate.gov/pdf/AHP-Final-02-17-06.pdf (pressing for Association Health Plans to reach the Senate floor for a vote); Olympia Snowe, AHPs are a Matter of Fairness, Sept. 14, 2005, available at $\mathrm{http} / / / \mathrm{sbc}$.senate.gov/republican/pdf/SBHP-TheHill-Op-ed.pdf(stating "[The proposed AHP legislation] unleashes the power of the competitive market to provide small businesses with more choices when it comes to securing affordable, quality insurance coverage."); Rob Kaiser, Association Health Plans Seek Strong Dose of Support, CHI. TRIB., Feb. 10, 2003, at Business pg. 1 (highlighting the recent momentum that AHPs have been gaining); Albert B. Crenshaw, Small Firms Pushing to Level Health Coverage Playing Field; Benefits: Business Groups Lobby for Change in Law to Let Them Band Together to Buy Coverage, L.A. TIMES, Feb. 28, 2001, at C7 (discussing small business owners' desire to purchase health coverage collectively). 
gress. The most promising solution addressing the needs of small businesses are AHPs, which spread risk among many small business owners, allowing them to expand their business and employee base without worrying about the health care expenses associated with growth.

Regardless of how a solution is obtained, the bottom line is that there are currently too many hardworking Americans and families who are not guaranteed access to quality health care. Short of the United States government assuming the role of health care provider, it is difficult to envision equal access to health care for all Americans becoming a reality in the near future. In theory, while HSAs seem to provide an adequate solution to controlling costs and subsequently increasing access, the fact remains that a segment of the population is effectively excluded by their implementation. Congress and the President can continue an incremental approach to fixing the system, some of which may be successful in addressing the needs of small segments of the population, but without legislation creating a government run and universal health care system there is no guarantee that each American will be assured immediate access to health care. It is precisely this lack of a guarantee to health care that piecemeal approaches have been unsuccessful in remedying. 